\title{
Restorasi Taman Beji Sapta Resi sebagai Wisata Religi di Desa Adat Samuan: Persepsi Masyarakat dan Implikasinya
}

I Made Putra Aryana 1

${ }^{I}$ Fakultas Dharma Acarya UHN I Gusti Bagus Sugriwa Denpasar, Email: madeputra84@gmail.com

\section{ABSTRAK}

Artikel ini bertujuan untuk mendeskripsikan persepsi masyarakat dan implikasi yang ditimbulkan dari adanya restorasi Taman Beji Sapta Resi. Restorasi yaitu pengembalian fungsi beji ke fungsinya semula. Artikel ini adalah hasil penelitian yang dilakukan dengan menggunakan metode pengumpulan data berupa observasi, wawancara, studi kepustakaan dan dokumentasi, dengan analisis data deskriptif kualitatif. Restorasi taman beji dilakukan karena adanya pengetahuan tentang adanya beji dan dikembalikan fungsinya sebagai beji yang memiliki panorama alam yang bernilai ekonomis. Potensi dibukanya Taman Beji Sapta Resi sebagai atraksi wisata antara lain: keadaan alam yang alami di sekitar Taman Beji Sapta Resi, pengembangan fasilitas pariwisata, dan pengelolaan objek wisata. Persepsi masyarakat terhadap dibukanya Taman Beji Sapta Resi sebagai tempat wisata religi adalah efisiensi dalam pelaksanaan prosesi masucian pratima, adanya tempat untuk melakukan meningkatkan kesucian diri, terbukanya lapangan kerja bagi masyarakat sekitar sehingga berdampak pada kesejahteraan masyarakat dan menambah pemasukan dana desa. Sehingga dampak yang ditimbulkan berupa dampak ekonomi, sosial dan budaya serta lingkungan.

Kata Kunci: restorasi, taman beji sapta resi, wisata religi

\section{ABSTRACT}

This article aims to describe community perceptions and the implications of the restoration of Taman Beji Sapta Resi. Restoration, namely returning the beji function to its original function. This article is the result of research conducted using data collection methods in the form of observation, interviews, literature study and documentation, with qualitative descriptive data analysis. The taman beji restoration was carried out because of knowledge of the existence of beji and its function was restored as beji which has a natural panorama of economic value. The potential for opening Taman Beji Sapta Resi as a tourist attraction includes: natural conditions around the Taman Beji Sapta Resi, development of tourism facilities, and management of tourist attractions. The public's perception of the opening of Taman Beji Sapta Resi as a place of religious tourism is efficiency in the implementation of the Masucian Pratima procession, the existence of a place to increase self-purity, open employment opportunities for the surrounding community so that it has an impact on community welfare and increases the income of village funds. So that the impact will be in the form of economic, social, cultural and environmental impacts.

Keywords : restoration, taman beji sapta resi, religious tourism

Copyright C2021. UHN IGB Sugriwa Denpasar. All Right Reserved 



\section{PENDAhUluan}

Air merupakan sarana penting dalam pelaksanaan upacara keagamaan agama Hindu. Air merupakan symbol amertha dan menjadikan badan tetap bersih dan suci. Semua peralatan juga harus dibersihakan dan disucikan dengan sarana air. Percikan air suci kepada seseorang dalam upacara bermaksud untuk mendapatkan kesehatan, ketentraman dan kebahagiaan. Air dianggap memiliki kekuatan untuk melenyapkan pengaruhpengaruh jahat. Demikian pentingnya air dalam kehidupan beragama dalam agama Hindu.

Suardana (2016) menguraikan tirtha berfungsi untuk membersihkan diri dari kotoran maupun kecemaran pikiran. Tirtha dalam penerapan pemakaiannya yaitu dipercikan di kepala, diminum dan diusapkan dimuka. Itu sebagai simbolis pembersih bayu, sabda dan idep. Dalam melakukan persembahyangan tirtha terbagi menjadi dua jenis yaitu Tirtha Pembersih dan tirtha wangsuhpada. tirtha pembersih berfungsi untuk menyucikan upakara (bebanten) yang dipakai sarana persembahan dan juga dipakai untuk menyucikan diri dari segala kekotoran. Biasanya tirtha pembersihan dipergunakan sebelum inti persembahyangan dilakukan. Setelah upakara dan diri sendiri diperciki tirtha pembersihan baru dilangsukan persembahyangan. Sedangkan tirta wangsuhpada merupakan lambang karunia / wara nugraha Ida Bhatara kepada umat yang memuja berupa amrta (kehidupan yang sejahtera). Biasanya tirtha wangsuhpada dipergunakan ketika persembahyangan selesai. Jadi fungsi tirtha dalam persembahyangan adalah sebagai pembuka dan penutup persembahyangan.

Jika ditinjau dari fungsinya tirtha dapat dibedakan menjadi: tirtha pembersihan, penglukatan, wangsuhpada, pemanah, penembak, dan pengentas. Dapat disimpulkan sesungguhnya Tirtha adalah benda materi yang sakral, yang mampu menumbuhkan perasaan dan pikiran yang suci. Jadi Tirtha bukanlah air biasa semata. Dan untuk membuktikan kesucian tirtha harus dilandaskan pada kepercayaan, karena tirtha adalah sarana agama. Dalam membuktikan kebenaran agama dasar utamanya adalah kepercayaan. Jadi tanpa dilandaskan kepercayaan tidak akan mampu membuktikan bahwa tirtha bukanlah air biasa. Jadi kita harus dapat mengayakini diri kita bahwa didalam tirtha terdapat kekuatan spiritual dari para dewa sebagai manifestasi Tuhan Yang Maha Esa.

Mata air di Pura Taman Beji yang konon pada zaman dahulu dipakai tempat patirthan oleh masyarakat luas. Kian berjalannya waktu sumber mata air tersebut terlupakan karena jalan/jalur untuk mencapai sumber mata air tersebut sangat curam dan bersemak-semak. Sehingga sumber mata air tersebut tak terjamah lagi. Seiring berjalannya waktu muncul ide untuk merestorasi sumber mata air yang telah terlupakan tersebut serta dikembangkan sebagai objek wisata religi yang dibuka untuk masyarakat umum. Sehingga dibuka akses jalan dan penataan jalan, penataan tempat suci dan penataan tempat penglukatannya.

Pura Taman Beji di Desa Adat Samuan semula kurang mendapatkan perhatian dari masyarakat maupun dari pemerintah setempat. Seiring berjalannya waktu, ada inisiatif dari Bendesa Adat Samuan untuk melakukan restorasi terhadap Pura Taman Beji tersebut. Oleh masyarakat pura tersebut dipercaya memiliki vibrasi kesucian, daya tarik wisata dan keasrian alam yang indah. Suatu tempat atau pura dapat menjadi atraksi wisata religi karena ada potensi. Potensi tersebut tidak hanya terkait dengan pura, tetapi juga diperkuat oleh aspek-aspek lainnya. Karena adanya aspek-aspek pendukung, keberadaan pura Taman Beji Sapta Resi akhirnya dijadikan objek wisata religi oleh krama Desa Adat Samuan. Pura sebagai atraksi wisata dapat memunculkan dampak positif dan negative. Keberadaan pura, demikian pula keberlangsungan kehidupan masyarakat di Desa Adat Samuan 
akan terdampak dari dijadikannya pura taman beji sebagai objek wisata religi. Dampak yang ditimbulkan tentunya ada yang bersifat positif dan negative.

Dengan demikian perlu dilaksanakan penelitian yang memfokuskan pada restorasi dan pengembangan teman beji tersebut yang disebut Taman Beji Sapta Resi yang ada di Desa Adat Samuan. Potensi-potensi yang ada sehingga Pura Taman Beji Sapta Resi dijadikan objek wisata religi. Dengan adanya objek wisata religi di Desa Adat Samuan, tentunya akan berdampak kepada masyarakat di Desa Adat Samuan itu sendiri. Sehingga akan diteliti juga persepsi masyarakat terhadap dampak yang muncul sebagai akibat Pura Taman Beji Sapta Resi dibuka sebagai objek wisata religi.

\section{HASIL DAN PEMBAHASAN}

Desa Adat Samuan adalah sebuah desa adat yang terdiri dari dua banjar dinas yaitu banjar dinas Samuan Kangin dan Banjar Dinas Samuan Kawan. Kedua banjar dinas tersebut di bawah naungan desa administrasi Desa Carangsari. Desa Adat Samuan terdiri dari tiga banjar adat yaitu Banjar Samuan Kangin dan Banjar Samuan Kawan dan Banjar Adat Jemeng. Desa Adat Samuan terletak di Kecamatan Petang Kabupaten Badung.

\section{A. Restorasi Taman Beji Sapta Resi}

Teori Fungsionalisme struktural yang dipelopori oleh Talcot Parson, sebagai asumsi dasar dari teori ini adalah paham atau perspektif dalam sosiologi yang memandang masyarakat sebagai satu sistem yang terdiri dari bagian-bagian yang saling berhubungan satu sama lain dan bagian yang suatu tidak dapat berfungsi tanpa adanya hubungan dengan bagian yang lainnya. Kemudian perubahan yang terjadi pada satu bagian yang akan menyebabkan ketidakseimbangan dan pada gilirannya akan menciptakan perubahan pada bagian lainnya.

Perkembangan fungsionalisme didasarkan model perkembangan sistem organisasi yang didapat dalam biologi, asumsi dasar teori ini adalah bahwa semua elemen harus berfungsi sehingga masyarakat dapat menjalankan fungsinya dengan baik. Masyarakat terintegrasi atas dasar kesepakatan dari para anggota akan nilainilai kemasyarakatannya tertentu yang mempunyai kemampuan mengatasi perbedaan-perbedaan sehingga masyarakat tersebut dipandang sebagai suatu sistem yang secara fungsional terintegrasi dalam suatu keseimbangan. Dengan demikian masyarakat merupakan kumpulan sistem-sistem sosial yang satu sama lain berhubungan dan saling ketergantungan.

Teori ini dipakai perspektif untuk mengkaji pelaksanaan restorasi terhadap Pura Taman Beji Sapta Resi. Ritual agama Hindu yang terselenggara oleh sebuah sistem kerjasama social yang mengoptimalkan masing-masing fungsi dari setiap unit organisasi social dan religi. Keberadaan Pura Taman Beji Sapta Rsi di Taman Beji Desa Adat Samuan merupakan unit yang mempunyai andil sebagai sarana proses ritual, dengan demikian tirta tersebut memiliki fungsi sosiologis telah terstruktur secara sistematis.

Teori Fungsional berkaitan dengan restorasi taman Beji Sapta Resi, bahwa adanya rencana dari stakeholder Desa Adat Samuan, memberikan peluang masyarakat dibawahnya untuk melakukan restorasi dan menikmati hasil dari restorasi tersebut.

Pengembangan

Pariwisata berdasarkan konsep Tri Murti, yaitu adanya usaha-usaha perencanaan, pengembangan dan pengembalian ke asal apabila sudah memberikan efek yang kurang baik. Perencanaan sudah dilakukan oleh bendesa Adat Samuan (prajuru) dan disetujui oleh masyarakat. Selanjutnya diresmikan oleh masyarakat Desa Adat Samuan dan dibuka untuk umum. Sampai saat ini masih tetap dilakukan pengembangan-pengembangan terhadap taman beji untuk meningkatkan kualitas taman beji. 


\section{a. Taman Beji sebelum Direstorasi}

Dibalik curamnya sebuah sungai di pedesaan memiliki panorama alam yang masih alami dengan keindahannya yang sangat menawan hati. Terdapat berbagai tumbuhan baik lelumutan, semak-semak dan pepohonan di pinggir sungai. Di pinggir sungai terdapat tebing batu padas. Warga samuan khususnya warga Banjar Jemeng ada beberapa yang berprofesi sebagai penambang batu pada di pinggir sungai Penet. Batu padas hasil tambang warga di pinggir sungai Penet dipakai membangun bangungan suci (sanggah/merajan) ataupun bangunan rumah adat Bali. Hasil tambang batu padas ada juga yang dijual, bahkan sampai terjual ke luar ke luar Desa Adat Samuan.

Keadaan satwa liar di wilayah sungai penet masih alami. Suara kicauan burungburung yang belum terusik oleh manusia, binatang-binatang melata di pepohonan, binatang melata di tanah yang membuat lubang untuk rumah mereka. Bahkan terdapat beberapa kera yang kadang datang bergelayutan di pepohonan untuk mencari makan.

Keadaan wilayah sekitar sungai penet dari wilayah Desa Adat Samuan sangatlah indah, tanahnya jarang terjamah oleh orangorang. Dari Banjar Jemeng ada jalan beberapa setapak yang menuju ke sungai. Keadaan jalan tersebut sangat curam, sulit dilalui. Jalan-jalan tersebut dipakai untuk orang yang sangat berkepentingan ke sungai. Lebih sering dipakai oleh para penambang batu padas di tebing-tebing sungai.

Di sisi utara wilayah Desa Adat Samuan di pinggir sungai Penet merupakan kawasan suci, yang konon dari dulu merupakan beji. Terdapat mata air yang muncul dari tanah (bebatuan) yang airnya terus mengalir. Kalau dibuatkan saluran akan membentuk sebuah pancoran yang airnya tidak pernah habis.

Terdapat juga sebuah air terjun yang airnya merupakan air sungai yang merupakan pembuangan dan sisa dari saluran irigasi persawahan di atasnya. Air terjun tersebut akan sangat deras kalau musim penghujan dan akan surut kalau musim kemarau. Pada saat air terjun yang deras merupakan pemandangan yang indah dengan panorama yang masih alami.

Karena adanya pengetahuan tentang keberadaan taman beji dan keindahan alam di sekitar sungai Penet. Dilakukan survey dan disepakati untuk menata kawasan beji tersebut agar mudah diakses. Sehingga memudahkan ketika ada upacara di pura kahyangan tiga saat melakukan acara masucian ( $k a$ beji).

\section{b. Restorasi Taman Beji Sapta Resi}

Restorasi yang dimaksud adalah melakukan penataan pemulihan atau pengembalian terhadap suatu kawasan suci taman beji yang ada di Desa Adat Samuan. Bertahun-tahun tempat ini terlupakan oleh masyarakat kini ditemukan kembali. Penataan dari sebelumnya jalan menuju Taman Beji sangat terjal, bersemak-semak, sulit dilalui. setelah direstorasi ditata, dibuatkan tangga permanen lengkap dengan penyangga di samping tangga.

Restorasi dilakukan pada sumber air yang disebut beji. Sebelumnya beji tersebut hanyalah sumber mata air dari dalam tanah (tebing) yang mengalir bebas. Selanjutnya dibuatkan penataan terhadap sumber mata air tersebut, dibuatkan saluran yang berjumlah tujuh, karena memang konon dahulu kala sumber air tersebut berjumlah tujuh buah. Dibuatkan kolam untuk tempat melaksanakan penglukatan. Dibuatkan saluran air sebagai tempat limbah air sisa penglukatan. Pada bangunan suci semula hanya bangunan sementara yang di bali disebut turus lumbung, selanjutnya dibuatkan bangunan suci (padmasana) yang permanen. Ditata lengkap dengan kawasan sucinya (penyengker).

Secara garis besar dilaksanakan restorasi taman Beji Sapta Resi karena adanya keinginan dari pemegang kebijakan desa adat yaitu Bendesa Adat Samuan, 
menghidupkan kembali beji yang sudah lama terbengkalai. Rencana restorasi tersebut, diteruskan kepada masyarakat dan sampai akhirnya disetujui untuk melakukan restorasi dan sudah dibuka untuk umum sampai sekarang. Dapat diuraikan berbagai alasan dilakukan restorasi antara lain:

1. Alasan teologi; bahwa masyarakat Desa Adat Samuan memiliki sistem keyakinan untuk melakukan penyucian dengan sarana utama air yaitu sumber air yang memang sudah ada di Desa Adat Samuan. Adanya emosi keagamaan, bahwa masyarakat membutuhkan beji sebagai penyucian pratima dan penyucian diri secara fisiologis.

2. Alasan ekologis; kesadaran masyarakat untuk melestarikan alam di wilayah Desa Adat Samuan sesuai dengan fungsinya.

3. Alasan estetika; kesadaran di Desa Adat Samuan memiliki alam yang bernilai ekonomis yang perlu dikembangkan

4. Alasan ekonomis; dengan restorasi Taman Beji Sapta Resi dibuka sebagai wisata religi, akan memberikan peluang kerja kepada masyarakat, antara lain di bidang pelayanan jasa dan perdagangan sehingga meningkatkan kesejahteraan masyarakat.

5. Alasan religious; masyarakat secara bersama-sama menjaga kesucian taman beji sebagai beji pada saat piodalanpiodalan di pura-pura di wilayah Desa Adat Samuan.

\section{c. Pentingnya Taman Beji Sapta Resi sebagai Beji dan Tempat Penglukatan bagi Masyarakat}

Konsep hierarki kebutuhan dasar ini bermula dari Maslow (wikipedia.org: 2020), berdasarkan pengamatannya, didapatkan kesimpulan bahwa beberapa kebutuhan lebih diutamakan dibandingkan dengan kebutuhan yang lain. Contohnya jika individu merasa haus, maka individu akan cenderung untuk mencoba memuaskan dahaga. Individu dapat hidup tanpa makanan selama bermingguminggu. Tetapi tanpa air, individu hanya dapat hidup selama beberapa hari saja karena kebutuhan akan air lebih kuat daripada kebutuhan akan makan.

Kebutuhan-kebutuhan ini sering disebut Maslow sebagai kebutuhankebutuhan dasar yang digambarkan sebagai sebuah hierarki atau tangga yang menggambarkan tingkat kebutuhan. Terdapat lima tingkat kebutuhan dasar, yaitu:

1. kebutuhan fisiologis,

2. kebutuhan akan rasa aman,

3. kebutuhan akan rasa memiliki dan kasih sayang,

4. kebutuhan akan penghargaan dan

5. kebutuhan akan aktualisasi diri Maslow memberi hipotesis bahwa setelah individu memuaskan kebutuhan pada tingkat paling bawah, individu akan memuaskan kebutuhan pada tingkat yang berikutnya. Jika pada tingkat tertinggi tetapi kebutuhan dasar tidak terpuaskan, maka individu dapat kembali pada tingkat kebutuhan yang sebelumnya. Menurut Maslow, pemuasan berbagai kebutuhan tersebut didorong oleh dua kekuatan yakni motivasi kekurangan (deficiency motivation) dan motivasi perkembangan (growth motivation). Motivasi kekurangan bertujuan untuk mengatasi masalah ketegangan manusia karena berbagai kekurangan yang ada. Sedangkan motivasi pertumbuhan didasarkan atas kapasitas setiap manusia untuk tumbuh dan berkembang. Kapasitas tersebut merupakan pembawaan dari setiap manusia.

Masyarakat Desa Adat Samuan juga memiliki kebutuhan dasar. Kebutuhan tersebut jika dikaitkan dengan keberadaan taman Beji antara lain:

1. kebutuhan fisiologis, sebagai kebutuhan anak adanya tempat permandian di sungai Penet, dengan adanya akses jalan ke sungai.

2. kebutuhan akan rasa aman, memiliki rasa aman secara fisiologis untuk mendapatkan penyucian di Taman Beji.

3. kebutuhan akan rasa memiliki dan kasih sayang, dimunculkan 
dengan adanya kasih sayang terhadap tempat dan lingkungan di Taman Beji.

4. kebutuhan akan penghargaan, perhargaan terhadap tempat suci (beji) yang memang sudah ada dari dahulu.

5. kebutuhan akan aktualisasi diri, menunjukkan keberadaan taman beji yang dimiliki kepada khayalak ramai.

Keberadaan sebuah tempat suci sangat penting bagi suatu komunitas masyarakat tertentu untuk melaksanakan ajaran agama dalam kebersamaan dalam suatu komunitas.

Di Desa Adat Samuan sebagai sebuah desa adat memiliki Pura Kahyangan Tiga dan Pura Kahyangan Desa yang diempon oleh Desa Adat Samuan. Kahyangan Tiga merupakan syarat berdirinya suatu Desa Adat. Disamping beberapa Pura yang diempon oleh masing-masing banjar di Desa Adat Samuan. Keberadaan Taman Beji sangat dipentingkan oleh Desa Adat Samuan, pada saat pelaksanaan piodalan (upacara) di Pura di Desa Adat Samuan tentunya sebelum puncak piodalan dilakukan terlebih dahulu Ida Bhatara Masucian ke taman beji.

Sebelumnya masucian yang dilakukan diluar desa yang kalau ditempuh dengan berjalan kaki cukup jauh, kurang lebih $4 \mathrm{~km}$. Beji ini akan dipakai tempat penyucian piodalan di pura di wialayah Desa Adat Samuan pun penyucian Ida Bhatara di masing-masing pakubon (rumah) saat melaksanakan piodalan jelih.

Taman Beji Sapta Resi sudah ada sejak dahulu, kendalanya akses jalan mencapainya sangat sulit. Tempat ini sudah terkenal sebagai tempat suci untuk melaksanakan panglukatan penyucian baik Ida Bhatara maupun orang-orang secara umum. Di Taman Beji Sapta Resi sumber air memang berjumlah tujuh buah, yang muncul dari tebing (dalam tanah). Karena berjumlah tujuh buah sumber air diberi nama taman Beji Sapta Resi.
Taman Beji ini juga dibuka untuk pariwisata religi yang tentunya dengan syarat-syarat kesucian ketika memasuki wilayah tempat suci ini. Keberadaan tempat suci bagi suatu komunitas umat Hindu sangat penting sebagai media untuk melakukan atraksi individu maupun kelompok menghubungkan diri dengan Ida Sang Hyang Widhi Wasa. Desa adat Samuan merestorasi pura Beji yang memang sudah ada sejak dulu dan dikembangkan untuk kepentingan umat secara umum.

Pembangunan Taman Beji Sapta Resi memiliki arti yang sangat sangat bagi masyarakat khususnya masyarakat Desa Adat Samuan, dalam pelaksanaan upacara keagamaan di suatu pura di Desa Adat Samuan. Pada saat piodalan di pura, dilakukan penyucian ke sumber air atau ke laut. Sebelumnya acara mesucian dilakukan sumber mata air yang jauh, sekarang di desa adat Samuan sudah ada. Bagi masyarakat Samuan, taman beji Sapta Resi merupakan tempat untuk melakukan penyucian pribadi atau dikenal dengan melukat. Adanya suatu keadaan tidak baik karena suatu hal, secara sekala maupun niskala perlu disucikan. Adanya taman beji Sapta Resi, masyarakat melakukan pengukatan di taman beji di desa sendiri.

Keberadaan taman beji Sapta Resi sudah ada sejak dahulu, restorasi dilakukan untuk mengembalikan fungsi taman beji tersebut ke keadaan semula. Sumber air yang ada di taman beji Sapta Resi memang sudah ada, tidak dengan sengaja dilakukan penglukatan oleh orang-orang. jumlah sumber air di taman beji tersebut berjumlah tujuh dan disebut-sebut Sapta Resi dan dikenal sampai sekarang bernama Taman Beji Sapta Resi.

\section{B. Potensi Pura Taman Beji Sapta Resi sebagai Atraksi Pariwisata di Desa Adat Samuan Desa Carangsari Kecamatan Petang Kabupaten Badung}

Pariwisata adalah berbagai macam kegiatan wisata dan didukung berbagai 
fasilitas serta layanan yang disediakan oleh masyarakat, pengusaha, pemerintah, dan pemerintah daerah. Berdasarkan definisi tersebut, maka terdapat lima hal penting yang mendasari kegiatan pariwisata dan sudah dikembangkan di Taman Beji Sapta Resi Desa Adat Samuan, sesuai dengan teori pengembangan atraksi wisata:

1. Perjalanan wisata yang bertanggung jawab, artinya bahwa semua pelaku kegiatan pariwisata harus bertanggung jawab terhadap dampak yang ditimbulkan dari kegiatan pariwisata terhadap lingkungan alam dan budaya. Di Taman Beji Sapta Resi Desa Adat Samuan mengedepankan panorama alam yang alami tidak merusak lingkungan yang ada. Dilakukan restorasi dan penataan taman. Selalu menjaga kebersihan dengan penyediaan tempat sampah dan petunjukpetunjuk untuk selalu menjaga lingkungan agar tetap bersih dan rapi.

2. Kegiatan pariwisata dilakukan ke/di daerah-daerah yang masih alami (nature made) atau di/ke daerah-daerah yang dikelola berdasarkan kaidah alam. Taman Beji Sapta Resi merupakan daerah alami diperbaiki hanya dengan menambah akses jalan. Tirta yang ada pun merupakan air yang muncul secara alami, yang berjumlah tujuh sumber mata air.

3. Tujuannya selain untuk menikmati pesona alam, juga untuk mendapatkan tambahan pengetahuan dan pemahaman mengenai berbagai fenomena alam dan budaya. Taman Beji Sapta Resi, selain pengunjung menikmati panorama alam juga memperoleh kesucian melalui ritual penglukatan sesuai dengan kepercayaannya.

4. Memberikan dukungan terhadap usaha-usaha konservasi alam. Keadaan alam di Taman Beji Sapta Resi masih alami, sehingga pengunjung akan memperoleh pengetahuan tentang alam, satwa yang masih hidup alami seperti kera liar dan tebing-tebing yang ditumbuhi rerumputan.

5. Meningkatkan kesejahteraan masyarakat setempat. Dibukanya Taman
Beji Sapta Resi memberikan pemasukan pada pendapatan dana desa adat, selain itu membuka lapangan pekerjaan dan tempat usaha perdagangan bagi masyarakat sekitar.

Wisata budaya, yaitu perjalanan yang dilakukan atas dasar keinginan untuk memperluas pandangan hidup seseorang dengan cara mengadakan kunjungan ke tempat lain atau ke luar negeri, mempelajari keadaan rakyat, kebiasaan dan adat istiadat mereka, cara hidup mereka, kebudayaan dan seni meraka.

Salah satu yang menjadi suatu daya tarik terbesar pada suatu destinasi wisata adalah sebuah atraksi, baik itu berupa pertunjukan kesenian, rekreasi, atau penyajian suatu paket kebudayaan lokal yang khas dan dilestarikan. Atraksi dapat berupa keseluruhan aktivitas keseharian penduduk setempat beserta setting fisik lokasi desa yang memungkinkan berintegrasinya wisatawan sebagai partisipasi aktif seperti belajar tari, bahasa, membatik seperti yang ada di Desa Wisata Krebet, memainkan alat musik tradisional, membajak sawah, menanam padi, melihat kegiatan budaya masyarakat setempat, dan lain-lain.

Atraksi merupakan komponen yang sangat vital, oleh karena itu suatu tempat wisata tersebut harus memiliki keunikan yang bisa menarik wisatawan. Fasilitasfasilitas pendukungnya juga harus lengkap agar kebutuhan wisatawan terpenuhi, serta keramahan masyarakat tempat wisata juga sangat berperan dalam menarik minat wisatawan. Faktor-faktor tersebut harus dikelola dengan baik, sehingga menjadikan tempat tersebut sebagai destinasi wisata dan wisatawan rela melakukan perjalanan ke tempat tersebut.

Berdasarkan uraian di atas dapat disimpulkan bahwa destinasi wisata merupakan interaksi antara berbagai elemen. Ada komponen yang harus dikelola dengan baik oleh suatu destinasi wisata adalah wisatawan, wilayah, dan informasi mengenai wilayah. Atraksi juga merupakan komponen vital yang dapat menarik minat wisatawan 
begitu juga dengan fasilitas-fasilitas yang mendukung di Pura Taman Beji Sapta Resi di Desa Adat Samuan.

\section{a. Keadaan Alam di Lingkungan Pura Taman Beji Sapta Resi}

Berdasarkan observasi yang dilakukan, Dibalik curamnya sebuah sungai di pedesaan memiliki panorama alam yang masih alami dengan keindahannya yang sangat menawan hati. Terdapat berbagai tumbuhan baik lumut, semak-semak dan pepohonan di pinggir sungai. Di pinggir sungai terdapat tebing batu padas. Warga samuan khususnya warga Banjar Jemeng ada beberapa yang berprofesi sebagai penambang batu pada di pinggir sungai Penet. Batu padas hasil tambang warga di pinggir sungai Penet dipakai membangun bangungan suci (sanggah/merajan) ataupun bangunan rumah adat Bali. Hasil tambang batu padas ada juga yang dijual, bahkan sampai terjual ke luar ke luar Desa Adat Samuan.

Keadaan satwa liar di wilayah sungai penet masih alami. Suara kicauan burungburung yang belum terusik oleh manusia, binatang-binatang melata di pepohonan, binatang melata di tanah yang membuat lubang untuk rumah mereka. Bahkan terdapat beberapa kera yang kadang datang bergelayutan di pepohonan untuk mencari makan.

Keadaan wilayah sekitar sungai penet dari wilayah Desa Adat Samuan sangatlah indah, tanahnya jarang terjamah oleh orangorang. Dari Banjar Jemeng ada jalan beberapa setapak yang menuju ke sungai. Keadaan jalan tersebut sangat curam, sulit dilalui. Jalan-jalan tersebut dipakai untuk orang yang sangat berkepentingan ke sungai. Lebih sering dipakai oleh para penambang batu padas di tebing-tebing sungai.

Di sisi utara wilayah Desa Adat Samuan di pinggir sungai Penet merupakan kawasan suci, yang konon dari dulu merupakan beji. Terdapat mata air yang muncul dari tanah (bebatuan) yang airnya terus mengalir. Kalau dibuatkan saluran akan membentuk sebuah pancoran yang airnya tidak pernah habis.

Terdapat juga sebuah air terjun yang airnya merupakan air sungai yang merupakan pembuangan dan sisa dari saluran irigasi persawahan di atasnya. Air terjun tersebut akan sangat deras kalau musim penghujan dan akan surut kalau musim kemarau. Pada saat air terjun yang deras merupakan pemandangan yang indah dengan panorama yang masih alami.

\section{b. Pembangunan Fasilitas-Fasilitas Penunjang Pariwisata}

Dari wawancara dan observasi yang dilakukan, diperoleh pengetahuan bahwa Taman Beji Sapta Resi sudah dibuka dan dilakukan upacara peresmian secara Hindu, sehingga resi sudah bisa dipakai sesuai peruntukannya. Semenjak dibuka, pada saat hari suci Banyu Pinaruh sudah dipadati pengunjung yang ingin melakukan penglukatan dari desa adat Samuan dan dari luar desa adat Samuan.

Dibukanya taman Beji Sapta Resi untuk umum sebagi objek wisata, maka dibangunlah fasilitas-fasilitas penunjang pariwisata. Pembangunan tersebut bertujuan untuk keselamatan pengunjung, kenyamanan pengunjung dan terkelolanya taman beji dengan baik. Fasilitas yang secara bertahap sudah dipersiapkan antara lain tepat ganti pakaian, peminjaman pakaian melukat, tersedianya tempat-tempat sampah, petunjuk-petunjuk jalan, petunjuk urutan penglukatan, listrik penerangan, tempat peristirahatan, lahan parkir, WC yang masih menggunakan WC milik warga sekitar, dan lain sebagainya.

\section{c. Petugas Penunjang Kegiatan Wisata Religi}

Dibukanya taman beji Sapta Resi sebagai tempat wisata religi, tentunya didukung dengan pengelola yang selalu siap untuk melakukan kegiatan pengelolaan demi kenyamanan pengunjung. Adapan pengelola 
di taman beji Sapta Resi antara lain, petugas parkir, petugas kebersihan dan taman. Pemangku (pinandita) yang bertugas setiap hari, dibagi berdasarkan piket pamangku pura secara bergilir. Petugas pengayah di tempat penglukatan juga secara bergilir ada di atam beji Sapta Resi. Dengan adanya pengelola dan pengayah tersebut, menjadikan taman beji Sapta Resi bersih, teratur, dan melayani pengunjung yang datang untuk malukat.

\section{Persepsi Komunitas Lokal terhadap Dampak yang Muncul sebagai Akibat Dijadikannya Pura Taman Beji Sapta Resi sebagai Wisata Religi}

Pengembangan pariwisata dapat menimbulkan berbagai dampak. Secara umum dampak yang ditimbulkan adalah dampak positif dan negative. Dampak positif meliputi: memperluas lapangan kerja, bertambahnya kesempatan berusaha, meningkatkan pendapatan, terpeliharanya kebudayaan setempat, terkenalnya budaya oleh wisatawan. Sedangkan dampak negatif dari pariwisata akan menimbulkan: tekanan penduduk akibat adanya pendatang baru, timbulnya komersialisasi, berkembangnya pola hidup konsumtif, terganggunya lingkungan, semakin terbatasnya lahan pertanian, pencemaran budaya, dan terdesaknya masyarakat setempat (0leh Spillane, 1989: 47, diakses dari: file.upi.edu/Direktori/FPIPS: 2020.

Secara umum restorasi dan dibukanya taman beji Sapta Resi sebagai wisata religi memberikan dampak kepada masyarakat, antara lain:

1. Ekonomi; terbuka lapangan pekerjaan baru yaitu pelayanan jasa dan perdagangan bagi sebagian masyarakat

2. Social; kehidupan masyarakat akan lebih terbuka secara sosial dengan adanya pengunjung-pengunjung yang melukat di taman beji dari luar desa/daerah, dan proteksi terhadap perilaku-perilaku yang kurang baik

3. Budaya; menjaga dan melestarikan serta memperkenalkan budaya setempat melalui beji dan pelaksanaan penyucian di beji Sapta Resi, proteksi terhadap budaya luar dan selalu meningkatkan kesucian taman beji Sapta Resi

4. Lingkungan; melestarikan lingkungan alam yang alami dan memberikan manfaat ekonomis sebagai objek wisata, serta selalu menjaga lingkungan terhadap perilaku yang abai terhadap kelestarian lingkungan.

Restorasi terhadap Taman Beji Sapta

Resi berimplikasi terhadap keberadaan masyarakat khususnya masyarakat Desa Adat Samuan. Secara sacral, taman beji memberikan nilai religius tentang keberadaan sumber air yang disucikan untuk kepentingan keagamaan di Desa Adat Samuan. Secara profan, taman beji memberikan dampak kepada pelaksanaan pembersihan diri (permandian) di sungai Penet.

Filosofis tirtha di Taman Beji Sapta Resi berupa kekuatan Tuhan yang terwujud dalam bentuk air, dapat memberikan kesucian kekuatan dan melebur segala kekotoran pada diri manusia, yang tentunya didasarkan atas kepercayaan. Keberadaannya tirtha tersebut terjadi secara interaksi antara orang-ke orang lain sesuai dengan fungsinya. Sehingga dapat disimpulkan terjadi interaksi simbolik antara orang ke orang terhadap filosofis kekuatan Tuhan dalam wujud air.

Dibukanya Pura Taman Beji Sapta Resi di Desa Adat Samuan, Kecamatan Petang, Kabupaten Badung sebagai wisata religi tentunya akan berdampak terhadap kehidupan sosial, ekonomi, budaya, agama dan lingkungan setempat. Dampak tersebut tentunya ada yang bersifat positif, ada pula yang negatif. Penelitian ini akan mengkaji persepsi masyarakat terhadap dampak yang ditimbulkan dengan dijadikannya Pura Taman Beji Sapta Resi sebagai wisata religi di Desa Adat Samuan Desa Carangsari, Kecamatan Petang, Kabupaten Badung.

Taman Beji Sapta Resi secara umum memberikan dampak positif terhadap kehidupan masyarakat: 
1. Efisiensi waktu dan tenaga pada saat rangkaian pesucian pidalan di pura

2. Mempermudah akses untuk melakukan panglukatan secara pribadi

3. Menciptakan taman rekreasi

4. Membuka lapangan kerja baru

5. Dikenalnya Desa Adat Samuan sebagai lokasi taman beji Sapta Resi

\section{a. Taman Beji Sapta Resi Sebagai Beji Pura di Desa Adat Samuan}

Dari wawancara yang dilakukan diperoleh pengetahuan bahwa di Desa Adat Samuan sebagai sebuah desa adat memiliki Pura Kahyangan Tiga dan Pura Kahyangan Desa yang diempon oleh Desa Adat Samuan. Kahyangan Tiga merupakan syarat berdirinya suatu Desa Adat. Disamping beberapa Pura yang diempon oleh masingmasing banjar di Desa Adat Samuan. Keberadaan Taman Beji sangat dipentingkan oleh Desa Adat Samuan, pada saat pelaksanaan piodalan (upacara) di Pura di Desa Adat Samuan tentunya sebelum puncak piodalan dilakukan terlebih dahulu Ida Bhatara Masucian ke taman beji.

Sebelumnya masucian yang dilakukan ngayat (menghaturkan upacara dari jauh) yaitu dari jalanan sebelum menuju tempat tirta. Ataupun masucian dilakukan di taman beji di luar desa yang kalau ditempuh dengan berjalan kaki cukup jauh, kurang lebih $4 \mathrm{~km}$. Beji ini akan dipakai tempat penyucian piodalan di pura di wilayah Desa Adat Samuan pun penyucian Ida Bhatara di masing-masing pakubon (rumah) saat melaksanakan piodalan jelih. Tempat ini sudah terkenal sebagai tempat suci untuk melaksanakan panglukatan penyucian baik Ida Bhatara maupun orang-orang secara umum. Sumber air di tempat ini memang ada demikian, tidak dibuat atau ditampung dahulu, kemudian dibuat saluran dengan jumlah yang diinginkan. Di Taman Beji Sapta Resi sumber air memang berjumlah tujuh buah, yang muncul dari tebing (dalam tanah). Karena berjumlah tujuh buah sumber air diberi nama taman Beji Sapta Resi.

\section{b. Taman Beji Sapta Resi Menambah Lapangan Pekerjaan Baru bagi Warga Desa Aat Samuan}

Dibukanya taman beji Sapta Resi sebagai objek wisata religi di Desa Adat Samuan memang dirasakan berbagai manfaatnya baik di bidang keagamaan, demikian juga sector perekonomian.

Pemangku sebagai pengayah pamangku di Desa Adat yang kegiatannya tidak rutin, dapat mengisi waktunya untuk ngayah di Pura taman Beji yang setiap hari ada kegiatan. Sebagai juru parkir dan pertamanan di taman beji juga dilakukan karena hobi juga karena tidak memiliki pekerjaan lain sebagai ayah-ayahan di desa.

Sebagai peternak sapi yang kerjanya hanya setiap pagi, dapat mengisi waktu ngayah di taman beji dari siang sampai sore, bahkan malam pun bisa. Keponakan pun ikut membuka warung makan, minuman dan camilan di parkiran taman beji karena memang pengunjung cukup ramai, di selasela kegiatannya bertani.

\section{c. Taman Beji Sapta Resi Menambah Pendapatan Dana Desa Adat Samuan}

Walaupun ada pengeluaran untuk operasional Taman Beji Sapta Resi baik untuk Petugas-petugas yang bertugas sebagai pengayah di Taman Beji Sapta Resi memang ada, yang dibayar honorariumnya dari kas keuangan Desa Adat Samuan. Petugas parkir dan perkebunan. Pamangku yang bertugas memimpin upacara kalau ada pemedek (orang yang melukat). Petugas yang membantu pemedek menyirati tirtha di berbagai tempat panglukatan di taman Beji.

Bagi masyarakat selain mempermudah akses ke Taman Beji dan saat Piodalan di Pura juga dirasakan manfaatnya untuk menambah pemasukan dana sebagai kas Desa Adat. Pemasukan per tahun dari pengelolaan Taman Beji sebagai Wisata Religi mencapai puluhan juta. Walaupun punia dan sesari bagi pemedek yang datang 
untuk malukat tidak dipatok atau dipasang tariff, tetapi keikhlasan pemedek yang datang menghaturkan punia yang dimasukkan ke dalam kotak kaca yang dipasang di Taman Beji Sapta Resi. Dana tersebut masuk ke kas Desa Adat dan dipakai untuk kepentingan operasional Desa Adat.

\section{d. Pengelolaan Taman Beji Desa Adat Samuan}

Sebagai objek wisata taman Beji Sapta Resi dibentuk petugas-petugas yang bertugas sebagai pengayah di Taman Beji Sapta Resi, yang dibayar honorariumnya dari kas keuangan Desa Adat Samuan. Antara lain Petugas parkir dan perkebunan yang mengkondisikan parkir dan selalu menata taman di di sepanjang tangga menuju taman baji dan taman di sekitar taman beji. Pamangku yang bertugas memimpin upacara kalau ada pemedek (orang yang melukat), adalah pemangku Kahyangan Tiga secara bergiliran setiap harinya. Petugas yang membantu pemedek menyirati tirta di berbagai tempat penglukatan di taman Beji. Pada saat ramai, misalnya pada saat hari banyu pinaruh masyarakat atau sekaha teruna Desa Adat Samuan pun ikut membantu dan begadang untuk operasional di taman beji. Karena saat banyu pinaruh pemedek yang datang sangat ramai, mulai dini hari, bahkan tengah malam sudah ramai..

\section{III.SIMPULAN}

Restorasi Taman Beji Sapta Resi sebagai wisata religi di Desa Adat Samuan, memiliki arti penting bagi masyarakat luas, khususnya masyarakat Desa Adat Samuan. Retorasi yang dimaksud adalah melakukan penataan pemulihan atau pengembalian terhadap suatu kawasan suci taman beji yang ada di Desa Adat Samuan. Pada saat pelaksanaan upacara keagamaan di suatu pura di Desa Adat Samuan, di Beji Sapta Resi dilakukan penyucian. Bagi masyarakat Samuan, taman beji Sapta Resi merupakan tempat untuk melakukan penyucian pribadi atau dikenal dengan melukat.
Restorasi dilakukan karena memiliki berbagai alasan antara lain alasan teologi, alasan ekologis, alasan estetika, alasan ekonomis dan alasan religious. Secara khusus restorasi dilakukan karena pertama, adanya pengetahuan tentang adanya beji yang sudah lama tidak terpakai, kedua, adanya panorama alam yang memiliki nilai ekonomis yang tinggi untuk dikembangkan.

Potensi dibukanya Taman Beji Sapta Resi sebagai atraksi wisata antara lain: keadaan alam yang alami di sekitar Taman Beji Sapta Resi, adanya tahapan-tahapan pengembangan fasilitas pariwisata di taman beji Sapta Resi, taman beji yang terkelola dengan baik. Restorasi tersebut sesuai sengan siklus Tri Murti, yaitu adanya perencanaan restorasi, pengembangan-pengembangan agar kualitas taman beji semakin meningkat dan pengembalian ke fungsi awal kembali apabila wisata religi sudah dominan memberikan dampak yang negatif.

Persepsi masyarakat terhadap dibukanya Taman Beji sapta Resi sebagai tempat wisata religi adalah efisiensi dalam pelaksanaan prosesi menyucikan pratima pada saat piodalan di pura di Desa Adat Samuan, adanya empat untuk melakukan penyucian diri (melukat) untuk meningkatkan kesucian diri, terbukanya lapangan kerja bagi masyarakat sekitar sehingga berdampak pada kesejahteraan masyarakat, menambah pemasukan dana desa, sehingga beban masyarakat semakin ringan di bidang ekonomi. Sehingga dampak yang ditimbulkan berupa ekonomi, sosial dan budaya serta lingkungan

\section{REFERENSI}

Anonim. 2010. Buku Pedoman Penulisan Usulan Penelitian Tesis, dan Desertasi. Denpasar: IHDN.

Beneh, I Wayan. 2005. Pancaka Tirtha di Taman Beji Tirtha Empul Tampak Siring (Telaah Bentuk, Fungsi dan Makna). IHDN Denpasar.

Dawson, Catherine. 2010. Metode Penelitian Praktis Sebuah Panduan. Yogyakarta: Pustaka Pelajar.

Moleong. 2002. Metodologi Penelitian 
Kualitatif. Bandung: PT. Remaja

Rosdakarya.

Nuryani, Sri. 2006. Penelitian Upacara

Bersih Pundhen Waty Girang Desa

Tampak Boyo Kecamatan Tawangsari

Kabupaten Sukoharjo: Kajian Bentuk, Fungsi dan Makna. Denpasar: UNHI.

Koentjaraningrat, 1981. Pengantar Ilmu Antropologi , Jakarta:Aksara Baru.

Suardana, I Made. 2016. Pura Tirta Empul sebagai Daya Tarik Wisata Budaya dalam Perspektif Teologi Hindu di Desa pakraman Manukaya Kecamatan Tampak Siring Kabupaten Gianyar. IHDN Denpasar.

Sudharta, Tjok Rai, 1992. Sungai Suci Gangga dan Yamuna. Surabaya: Paramita.

Soetriono dan Rita Hanafie. 2007. Filsafat Ilmu dan Metodologi Penelitian. Yogyakarta: Andi Offset.

Yasa, I Ketut Warta. 2006. Penelitian Pola Asuh Pembinaan Agama Hindu pada Keluarga Batih: Studi Kasus di Desa Carangsari Kecamatan Petang Kabupaten Badung. Denpasar: IHDN.

https://kbbi.web.id/, diakses 31 Januari 2020.

https://id.m.wikipidia.org. diakses 31 Januari2020.

http://file.upi.edu/Direktori/FPIPS/JUR._PE ND._GEOGRAFI/197210242001121BAGJA_WALUYA/GEOGRAFI_PAR IWISATA/Dampak_Pariwisata.pdf diakses 1 Mei 2020.

https://cvinspireconsulting.com/konseppengembangan-pariwisata/ diakses 1 Mei 2020.

https://id.wikipedia.org/wiki/Hierarki_kebutu han_Maslow diakses 15 Nopember 2020 . 